\title{
Language, Identity, and Gender: A Study of Creole in the Caribbean
}

\author{
Amitabh Vikram Dwivedi \\ School of Languages \& Literature, Shri Mata Vaishno Devi University, Katra Jammu-182 320, India \\ *Corresponding Author: amitabhvikram@yahoo.co.in
}

Copyright $@ 2015$ Horizon Research Publishing All rights reserved.

\begin{abstract}
This paper examines creolization of the Caribbean. It looks into creolization from three points of view namely linguistic, ethnic, and biological, and discusses language, identity, and gender of the Caribbean respectively. Any attempt to define creole becomes an area of continuing concern to question the very status of language. There has been a long chain of disagreement over the definitions of creole languages and how they are different from other languages. The various etymological points of view are discussed in the first section. The second section debates the mythical or the (Andersonian) imagined Caribbean identity and it talks about ethnic creolization. The final section discusses the biological creolization.
\end{abstract}

Keywords Creolization, Caribbean, Gender Relations, Ethnic Experiences, Imagined Community

\section{Introduction}

This paper examines creolization in the Caribbean. It looks into creolization from three points of view namely linguistic, ethnic, and biological, and discusses language, identity, and gender of the Caribbean respectively. Creole languages continue to defy definitions, [1] and any attempt to define Creole becomes an area of continuing concern to question the very status of language. There has been a long chain of disagreement over the definitions of Creole languages, and how they are different from others. The various etymological theories and dominating hypotheses from the baby talk theory to Bio program; and the pejorative assumptions and reactionary attitudes from gradualism to hyper-creolization have been discussed in the language section.

The second section debates the mythical or the (Andersonian) [2] imagined Caribbean identity and it talks about ethnic creolization. There are Aboriginal Indians, Africans, Asian Indians, Chinese, Europeans, Indonesian Javanese, and others who are Christians, Hindus, Muslims, Jews, Rastafarians, Santería, Winti, Vudun, and bear other religious identity who speak many tongues, namely Spanish,
English, Dutch, French, English, and different Creoles such as papiamentu, sranantongo, ndjuka, saramaccan, kromanti, kreyol, as well as Hindustani, Bhojpuri, Urdu, etc. Language, however, remains a critical marker of identity in the Caribbean. [3] In ethnic creolization, I have surveyed the historical and literary trends in this societal engagement in the Caribbean during the last seven decades, and found out the aspects and dimensions of the relationship among community, conflict, and identity observed in literature and social histories. Gender, a biological creolization, is discussed in the final section. Keeping the biological gender in the forefront, this section will discuss the gender relations with reference to women in the Caribbean. Though both the sexes constitute gendered identities yet the focus is on women here.

\section{General Framework}

The tactics of this paper is to study the Creole in the Caribbean, and the topics are language, identity and gender. This seemingly narrative history of mixture (languages, races, and persons) treats mixture as an effect of creolization dynamics that developed at the Caribbean after the arrival of the first European settlers in the fifteenth century. Each section, namely language, identity and gender is interrelated but independent to each other, and the role of the Creole (creolized and creolizing) is of an assessor which configures linguistic, ethnic, and biological creolization in the Caribbean. A historical background and temporal aspect-past and present- run parallel to each section e.g. the first section describes the play politics of linguists and historians in defining Creole ever since this term has been in vogue, and in the next section titled Identity, the sense of loss is mingled with the sense of gain, and this play of loss and gain of identity runs in the structure of the text, and in the terminal section, before I draw any conclusion, the argument presents the gender differences (both linguistic and biological) in the Creole languages.

These sections claim to present a study, and it is nowhere my attempt to set an inquiry, but my endeavor in the present study is to illustrate as explicitly as possible the process of 
creolization with respect to language, identity, and gender. I have not prescribed my judgment and suggestions but an objective description followed in line with the Weber's [4] axiological neutrality throughout. I have used the term 'creolization' with three different topics which are quite diverse in their scope. In this process of creolization in each heading the reader might find one process of creolization simpler than the other i.e. the creolization of language is easy to understand but the creolization of identity and gender is not. The linguistic creolization appears simple because it is apparent in many ways. The Creole languages adopted the content words, phonologically strong syllables, simple word-order with a loss of ordering possibilities from the European languages, and employed relexification or intertwining, [5] and convergence. The linguistic variations and specifications have been always a black-and-white issue but our knowledge is virtually zero of the history of most ethnic groups as Nash observes the term 'ethnicity' and 'ethnic groups' are the most complicated, fickle, and emotionally charged words and ideas in the lexicon of the study of society, [6] and moreover, the individual variety of language (idiolect) has never attained too much importance in studying languages whereas in identity and gender issues individual example becomes an exemplar for the whole. Therefore, creolization is not a formula here, but it is a metaphor which has been used for the process in which Creole culture emerges in the Caribbean. This culture is a mixture of newness of languages, the formation of new identities, and there is no surprise that any new element received by the world gets a mixed feeling of awe and contempt.

\section{Language}

The first time the term 'Creole' was applied to a language was in 1739 in the Virgin Islands. [7] Etymologically, the term 'Creole' has been derived from Portuguese 'crioulo' via Spanish and French, which means a white man of European descent who was born and raised in a tropical and semi-tropical colony. Cassidy says that only at later stages it was applied for non-European and slaves. [9] Except for few Creoles, such as Chinook Jargon and others in Africa, most of the Creoles have been derived from European languages. Haiti, French Guiana, Louisiana, and the Lesser Antilles Creoles have been derived from French, and also sometimes defined as the dialects of the French Creoles. The Creoles derived from English are spoken in West Africa, Cameroons, Sierra Leone, Jamaica, Trinidad and Tobago, British Guiana, British Honduras, Barbados, St. Lucia, St. Kitts, Anguilla, Nevis, the Netherlands' Antilles, Surinam, and Georgia, South Carolina. Negerhollands, a Dutch Creole, is spoken by a few residents of US Virgin Islands. Spanish and Portuguese based Creole is spoken in Cape Verde, Annobon, and Sao Tome.

Contact among different mutually unintelligible cultural and linguistic groups is responsible for the birth of pidgins and Creoles. Creole remains a nativized form of its predecessor pidgin which in turn is acquired by the children as their first natural language. In 1950s, Samuel Selvon had written The Lonely Londoners in Trinidadian Creole. ${ }^{9}$ This text has become a seminal work in Caribbean literature for refashioning a change in the perceptions and the complexities of language in the Caribbean, and pidgins and creoles have been popularized ever since. Jean Rhys's Wide Sargasso Sea [10] published in 1968 (also a year of second conference on Creole studies) captured the themes of assimilation, racial inequality, and displacement and became one of the 100 best English novels since 1923 by Time, and Cola Debrot's novel My Sister the Negress which was published in 1936 also rose from an obscurity then.

The pejorative overtones are not only limited to literature but also in the hypotheses pertaining to etymology of pidgins and creoles. In 1972, Hancock [11] indicated that 'pequeno Portuguese' used in Angola for the 'broken Portuguese spoken by illiterate Africans', and in 1876 Leland [12] defined pidgin 'business; affair; occupation' as a phonetic change/corruption of Portuguese 'ocupacho.' Similarly, one of the hypotheses considers that Creole as an English form has been derived from French 'Creole' and Portuguese 'criaulo' which means 'to breed, to bring up, to nourish'. There are also sufficient references to Creole which show its status as a language of an illiterate and rude people. One of the polygenetic theories describes each pidgin and creole originated as a baby-talk used by masters, plantation owners, and merchants to communicate with their servants, slaves, and customers, and each speaker destroyed the standard language by removing grammatical inflections, eliminating the number of phonological and syntactic contrasts, and limiting the vocabulary to few words. [13] This baby talk theory, which is now totally discarded, is described by few linguists as 'optimum' grammar rather than a more derogatory 'minimum' grammar. Keith Whinnom supported monogenetic theory and he claimed that Papiamento had its origin from Portuguese pidgin and four Spanish Creoles developed from a common source respectively. [14] In the same vein, William Stewart concluded that divergent relexification of a single proto-pidgin was a more defensible hypothesis than the convergent restructuring of separate languages. Whinnom suggested Sabir as the proto-Creole of all the European-based pidgins and Creoles. [15] Though monogenetic theory is largely accepted yet in some cases like Kituba, Chinook, Pitcairnese, and Amerindian Creole; Hall's theory of spontaneous generation [16] is applicable. McWhorter [17] showed the common typological features in all Creole languages, [18] and tried to distinguish them for other languages by showing little or no inflectional affixation and the use of tone, and semantically regular derivational affixation in the Creoles. [19]

The half-blood treatment for pidgins and Creoles by the linguists had been collapsed a few decades ago. Earlier, this study was highly compartmentalized, [20] and either the substrate (source language) influences of the languages of the creators of the Creoles or the superstrate (target language) 
influences of European languages were held responsible for the emergence of Creoles. Fortunately, there is a consensus now among the language experts to talk about Creole, and not of Creoles. They have been discussing the same linguistic process, and eschewing the more problematic term 'similar linguistic process' when they do their researches, and a linguistic progress had been observed when slowly but with deliberation they dropped the term 'mixed languages' for Creole and recognized them as other languages with an inferior social status. But Creoles are not ordinary languages quantitatively because they came into existence differently at some point of time; qualitatively, however, they are nowhere inferior to any other languages of the world. Researchers such as De Camp [21] and Bickerton [22] employ neologisms "such terms as "basilect," "mesolect," and "acrolect" $[\ldots]$ in order to categorize and label an abstracted and idealized Creole variety spoken by an individual or a community'. However, Bickerton's Bio program hypothesis, presented in 1975 Hawaii conference, states that there are fundamental semantactic (pertaining to the similar meaning) parallels between a numbers of proto-typical Creoles which dominates the debate in the field [23]. A few language experts present a Euro-centric model against Bio program which states the languages of the colonizers were solely responsible for the growth of the Creoles but eventually and vainly they presupposed an answer: which language provided the lexicon, and which provided grammar, and the supporters of gradualism, in order to lessen the effect of indigenous languages (a type of linguistic violence) in the creation of Creole languages, believe that many plantation holders found it cheaper to work their slaves to death and due to this reason Creoles developed gradually without the intervention of child language creators. [24]

The benefits of these studies for Creole are that there became a consensus to accept Creole as a language, and the language experts start believing that creolization may take place in a few decades. But if in a society an equivalent European language exists then Creole is generally treated as a corruption of language. And this leads to other sociolinguistic misassumptions that a Creole is equal to poverty, ignorance, and lack of moral character. At times, the voices were raised against such biased opinions. A national reaction against such misconception charged some areas of Sierra Leone, and they emphasized the linguistic superiority of Creole which is also known as 'hyper-creolization'. [25] But attitudes of the people in power and other corrective pressures from various institutions and schools can positively change the status of a Creole to a post-Creole when people are pressurized to believe it as a dialect or a language continuum of the standard language. On the other hand politicians have been exploiting the situation by making a subtle 'code-switching' move from a standard European language to a Creole during the period of election to allure the Creole speakers. [26]

But there remains the other side of the coin. In fifteenth century Spanish conquest to Caribbean enriched Spanish vocabulary, and it accumulated indigenous Caribbean and
African words. Porras observes, 'it certainly exhibits much of an influence in its lexicon. Just as in Medieval times, when Castilian [borrowed] words from other languages Latin American Spanish enriched its lexical stock with Native American languages such as Arawak (Taíno), Nahuatl, Mayan, Quechua, Tupí-Guaraní, Mapuche, and from African languages such as Kikongo, Kishigongo, Kimbundu, Ewe, and Yoruba', [27] but there is no gainsaying European presence had produced a huge deterioration in the conditions that existed for transmitting Creole languages to new generations of children. [28]

Today European creolization is a historical document, and the real danger is of the hostile treatment which the surviving indigenous language speaking communities have been facing for their Creole languages use. Sometimes this treatment is not obvious and directly felt but it is a conscious need realized by the indigenous people to engage them with the larger section of the society which makes them to switch from a native language variety to officially declared Creole language or adopted official European language of the country. And due to this replacement many indigenous languages have become endangered. Tunayuna, Akurio and Sikiiiyana, have only a few hundred speakers, and in Arawak and Garifuna the level of endangerment varies from community to community, and out of few hundred only above 50 year old 10-15 speakers are alive who can communicate in the language. [29] Official language policy is largely responsible to eliminate an indigenous Creole language with a standard European language. And Devonish has described this process as genocide. [30] The linguistic creolization has now transformed into a linguistic genocide.

Language alters our views, and everyone needs a language to create one's own identity. The Creole in the Caribbean tells this paradigm shift from language change (development) to the change of the status of Creole languages which has worked out to establish the linguistic identity of these languages. Though Haiti was the first Caribbean nation to identify Haitian as an official language yet the other Creole languages have not been established in educating the pupils and their use for instruction in schools is only a recent culture e.g. the official provisions for the use of Papiamentu in 1983; the concessions made in Trinidad and Tobago for the use of Creole at primary level in 1975; the teaching of French Lexicon Creole of St. Lucia and Dominica in metropolitan London. [31] The music industry is based on Creole, and the French, English, Jamaican, and Trinidadian Creole music is popular in youth. The development of FM broadcasting has increased the listeners of Creoles, and this helps to enhance the acceptability of vernaculars. These trends show undoubtedly a progressive pace.

In this section, I have shown how the linguistic creolization-the etymological development of Creole languages on the basis of linguistics-took place, and it is quite obvious that how ambiguous arguments over the genesis of Creole have portrayed a picture of uneven identities of the Caribbean but the arrival of black linguists into the field was a discerning factor in the development of 
the Creole hypothesis, and the distinctive features of the tense and aspect system had been recognized gradually. The interest in and discussion on Creole identity has turned out to be noticeable among different communities worldwide then. Considering the fact that comparatively more confusion exists in etymological study as we know little about the development of the most Creole languages, the frequent prejudice against their recognition will only cease when we will discuss more about the theories of origin that is to say similarity, simplicity, mixing, and variability, and rely less on assumption and more on explanation of their development.

\section{Identity}

Collective existence and experience of the people constitute identity. A sense of identity not only gives us pride and confidence but also fills us with strength and confidence.... and yet it can also kill. [32] Recent literature in the social sciences is teem with identity and its relation to ethnicity and community, on one side, and conflict, on the other, have appeared as the most important topics for investigation, and conflicts among communities have been observed as a spontaneous effusion for protecting a community's identity or an affirmation to protest against its violation. The focus of this section is socio-lingual.

In Caribbean, since there is no single Creole signaling the concept of identity explicitly, the room for understanding for the ethnic creolization emerges when we study how multiple/plural identities are signaled simultaneously in the region. Premdas presents four levels of identity in the Caribbean. The trans-Caribbean identity transforms the strangers-at- home into the brothers and sisters in the foreign land, the regional identity exists in different regions of the Caribbean where people share a single language, the insular identity develops among nations colonized by the same European country, and finally the substrate identity constructs on a diversity of deep cultural divisions. [33] The fact that 'identity issues' in the Caribbean do not have a common locus it would be meaningful here to take into consideration the people's concern with their collective identities. And here creolization becomes a 'syncretic process of transverse dynamics' that indefinitely revises and 'transforms the cultural patterns of varied social and historical experiences and identities'. [34]The antillanité or Caribbeanness and poétique de la relation or cross-cultural poetics in the similar vein has been expressed in the theoretical work of Glissant [35] where cultural pluralism, historical discontinuity, geographical fragmentation, and political insularity find place to express the caribbeanness, and the possible plural identities come under the cross-cultural poetics. Ethnic creolization, or rather say Caribbeanness in this section proudly produces the moderating of new laws and sadly sings the tales of the unlawful mixture. The cross-cultural poetics will be presented through the many facets of Creole languages.
The earlier historians and anthropologists were hopelessly biased towards the concept of an independent Caribbean identity. Anthropologist Drummond follows Derek Bickerton's Creole hypothesis and compares Caribbean culture with Creole languages, and sees it as discrete and rule-governed systems where 'adjustment and adaptability are key elements', [36] and Dallas asserted in the book published in nineteenth century that 'the notion of a free, active, negro republic does not seem to have any reasonable foundation'. [37] This argument is not totally vacuous when we see many Caribbean nations reluctantly maintaining their link with the colonizers, and the economic and political dominance and color-stratified concept are integrated around the accepted hierarchy of the colonizers. Until recently, however, there is an ideological consensus that there is a Caribbean identity though the study models range from plantations to plural societies.

The plantation model finds its voice in earlier literature, e.g. in a poem titled 'In Exilium', [38] the voice of protest for the illicit blending is so prevalent that it says it is disgraceful, insulting, and base that I am Ashanti, Congolese, and Yoruba but they address, call, and name me as Carlos, Guillermo, and Wilson respectively. A similar tone can be heard in Fred D'Aguiar's novel titled The Longest Memory who states 'In my own case, do I see myself as Spanish simply because my name is Spanish? Then what is my real name, the one that corresponds to my real identity? [...] However, no Caribbean person that is, no person with a truly Caribbean identity carries his or her own true name, just as his or her skin pertains to no fixed race'. [39]

The plural societies of the southern Caribbean regions, chiefly Surinam, Guyana, and Trinidad breed interethnic strife and contentions on the issues, chiefly related to the identification of the real black people, establishment through ethnic cleansing, engagement in a civil war, promotion in separatists' tendencies, institutionalization of color-class system, and last but not least, the growing disparity in per capita income and population between two islands. The present day Caribbean has forgotten about the commonly shared historical fact i.e. slavery, and they are mobilizing against the non-black people who have not shared the common colonial oppression. The Anglophone Caribbean has been facing a split between the brown few (elite) and the black many (masses), and this attitude is weakening the national identity. The ruling party, either African or non-African, has been often accused of ethnic cleansing. Premdas discusses the case of Trinidad, Guyana, and Suriname where the communities of Asian and African descent structurally dominate Chinese, Syrians, Lebanese, Jews, Portuguese, Europeans, Amerindians, and other mixes and combinations. But there is strife between these two groups which works against the solidarity of the nation, and the notoriety of the civil war in Surinam from 1986 to 1992 is an exemplar of such conflict. These twenty eight different islands show a huge variation in the statistics of population. The half of the Caribbean islands has only 5 , 68,000 persons which makes 1.34 percent of the total of 41 , 
937,000 which are populated by African, White, Dominican, Maroon, Asian, Asian-Indian, Javanese, etc. following different religions like Hindu, Muslim, Christian, and Jew, and their per capita income varies from $\$ 300$ to $\$ 20,000$ where Haiti is the poorest and Bermuda is the richest. [40]

Though it is quite convincing to think that the geography of the Caribbean has nothing common to share with its compatriots except sea, shore, sultry weather, and some Creoles yet it is much more than its geography. People speak various polyglots and create an imaginary identity where 'difference' is a commonly agreed word. Benedict Anderson talked about such community in his Imagined Communities where "the members of even the smallest nation will never know most of their fellow members, meet them, or even hear of them" and the so-called "communion" is always an imagined one. [41] But whenever any attempt had been made either in fiction or in real, the purpose is only one to establish an identity where 'we-they', 'inclusion-exclusion', and 'similar-other' relationships in the ethno-cultural groups are the psychological construct to get recognized. [42]

Within the limited scope of this section, I have discussed only the significant points with reference to identity. It is neither possible nor necessary to accommodate all the writings on the subject of identity. My discussion on identity of the Caribbean sums up with a note that though pluralities of identities exist but a society invokes only a specific identity depending upon the situation and context. And we have seen that at times Creole communities are "imagined" (Anderson) [43] and some identities are created, it is therefore crucial for the creolites to ascertain in times of conflicts and strife whether their identity is unique or illusionary. Interestingly, the quest for identity rests on the phenomenon which has been derived from the fact that Caribbean is not a single nation but a region with a plurality of nations, and any post-colonial effort to treat it as a nation will create contentions rather than to come up with any sensible solution.

\section{Gender}

The first gender relations in the Caribbean must have started when the indigenous men and women had celebrated the sharing and belonging of body, language, location, and identity within their communities. But the problems started with the advent of European imposed supremacy over the indigenous population of Arawaks, Caribs, Tainos, etc, and the new gender relations have been consuming the space in literature since then. Three century old slavery and no fewer than eight decades of indentureship have redefined these relationships. The Caribbean women had faced a concrete social phenomenon i.e. slavery. It is a historical fact now but in this section it is contextual, and it makes their study special and different in a way from the rest of the world. Besides that the issues related to production and reproduction in a patriarchy model remains similar in 'eurocentric', 'western', and 'ethnocentric' studies on women. The biological creolization is not based on the differences of 'black' and 'white' feminist theory because the Caribbean as a region reflects divergent perceptions, and different social and historical locations. Gender and ethnic experiences influence our views therefore I will start with how Caribbean women experienced her life in relation to Creole, and then I will move to the gender differences in the imagined community of supposedly same people.

Creole women were generally desired by the white men from the initial days of colonization. Various travelogues are filled with information on sexual attraction. One of such travelogues is by a Dutch traveler Francesco Carletti who describes them less harmful, more joyful and healthier in comparison to European women, and he recommends if someone fails to get married to such woman, he should try to secure one as a concubine. It is not a myth that Europeans came without women in pre-Columbian times and chose their wives from the Arawaks whom they held by physical force and conquered. In 1492, the three caravels the Santa María, the Pinta, and the Niña landed on the coast of the island of Quisqueya, where later Santo Domingo, the oldest Spanish colony in the New World, was founded. Wilson Harris says 'My mother and her middle-class family in British Guiana in the 1930s were called Creoles [...] Sometimes the term Creole was implicitly or covertly hurled at us like a metaphoric brick (designed to alert us to our impure lineage and mixed race) by the pure-blooded tenants'. [44] Carlos Guillermo Wilson also denounces the process of creolization which tries to erase the African culture, heritage and identity and consciously tries to make us unaware of the fact that 'the process of creolization which initially began with the rape of young African slave girls and which still persists today in the hatred concealed in the edict: it is necessary to better or improve the race'. [45] Vicioso in a paper 'Dominicanyorkness: A Metropolitan Discovery of the Triangle' talks about color identity where mere 'Indian' is no color. 'India clara' means 'light indian' and a dark Indian is known as 'indian-indian' and if someone were on a rather darker side he/she is 'cinnamon-indian'. [46] This supremacy or likeness for white and fair color has been defined by a Brazilian sociologist, Gilberto Freyre as ' $a$ Big house' view that culture filters in a top down fashion from the colonizer to the colonized. These differences of identities are based on color scheme where women are consciously trying to lessen the pain of their dark colors. [47] In a novel Los nietos de Felicidad Dolores (1991) C. G. Wilson says: 'In fact, I am very happy and, yes, very proud that there were five blond soldiers, yes, very blond with blue eyes, the ones that made me pregnant. All of them white '. [48] This fictional and promiscuous perspective will become more obvious when we take into account a historical fact into consideration. After 1863, most of the Surinamese families faced a loss of men and fathers in their families for several months. Mothers were left behind to bear the responsibility of children and a culture of mutually sharing a family responsibility developed. And massive migration in 1970s to the Netherlands only revived the old stories of discrimination 
and hatred. Gradually, in the absence of a constructive relationship with a male figure, a new religion name Winti (literally means 'wind') started. [49] Some sociolinguists identify creolization, migration and exploitation with plantation. And the rule of the thumb of this equation was instability.

Focus on history should not preclude the oddities of the present. But sadly too much emphasis on language and identity issues in the literature of the Caribbean has sidelined the gender studies of this region. The differences in sexes in the present day Caribbean are significant too than the differences in languages, identities, races and classes. Family structure and relationships are still carrying their antecedents in the plantation system, and the resultant is a 'complex family arrangement that the social and legal status of women are entangled' (Gordon). [50] Taking into account slavery and the post-colonial effect, the most of the children who were born outside a legal marriage are devoid of inheritance and the property rights. These family laws not only discriminate them on the grounds of a legal marriage but also deny the social realities of marriages without wedlock in the Caribbean during the colonial period. Clearly, the sexual experiences and experimentations are a punishment for women. Professional women of middle class have been facing legal discrimination too e.g. wives of Jamaican nationals were exempt from the need to get work permits in Jamaica, Trinidad and Tobago, Bahamas and Barbados.

In 1970s a number of issues related to women were taken into account while establishing the Women in the Caribbean Project (WICP), 1979-82, the Women and Development Unit, and the Women and Development Studies Project in the Caribbean to break the young girls confinement at their own home, to enhance young girls enrolments in schools for education, to provide sexual education, and to eradicate an undesirable position of women where they have often struggled with pregnancies and dependencies. Changes are required in the homeland in the Caribbean society for the issues which are still lingering and reminding them of the shackles of the old life of slavery e.g. the expectations of Barbadian society where women are only permitted to attend prayer meetings, weddings, funerals, and are supposed to perform wifely duties; the family dictatorship of father figures in the families in Puerto Rica where wives and children should abide by the social relations dictated by them; and the women must walk a certain distance behind their husbands in Carriacou, alike. The present Caribbean has been progressing but the development indicates the change of nomenclature: from the Centre for Women and Development Studies to the Centre for Gender and Development Studies in the University of West Indies.

\section{Conclusions}

The sections in this paper wipe the dust from the past; do a quick tidy-up to present a new ground in exploring issues of language, identity and gender for the future study. These sections seek not merely to explore these intersections but to study their meaningfulness in the context of Caribbean social reality. The temporal cycles-past and present-of each section have documented the conventional violence (linguistic, ethnic, and biological), and the usual prejudice for the Creole in the Caribbean. The present scenario though looks at the bright side yet it appears like it will do no more than simply reinforce existing prejudices. A journey to exotic should not end in esoteric. The accompanying bibliography show a wide range of works and intensive coverage that language, identity, and gender as a theme have received in the work of linguists, sociolinguists, historians, women studies experts, and social scientists. What is important and interesting here is that language has been discussed socio-linguistically, and the coverage is not limited to a particular Creole language group, to a single language, to a specific country, and gender has been conjunct with institutionalization, even an amorphous concept identity receives a treatment from linguistic points of view.

\section{REFERENCES}

[1] Mc Donald, H. S. and Robertson, I. Exploring the boundaries of Caribbean Creole Languages. UWI Press: Jamaica, 2006, p. xiv.

[2] Anderson, Benedict. Imagined Communities: Reflections on the Origin and Spread of Nationalism, London: Verso; 1983.

[3] Premdas, R. R. "Ethnicity and Identity in the Caribbean: Decentering a Myth" in Working Paper \#234. The Helen Kellogg Institute for International Studies: US; 1996, p. 24.

[4] Weber, Max, Hans Heinrich Gerth, and C. Wright Mills. From Max Weber: Essays in Sociology. New York: Oxford University Press, 1946.

[5] Bakker, P. "Rapid language change: creolization, intertwining, convergence" in C. Renfrew, A. McMohan and L.Trask (eds.) Time depth in historical linguistics, vol. 2: Cambridge; 2000, pp.576-610.

[6] Nash, Manning. The Cauldron of Ethnicity in the Modern World. University of Chicago Press: Cambridge; 1989, p.1.

[7] Muysken, Pieter and Paul Law. "Creole studies. A theoretical linguist's field guide." Glot International 5.2; 2001, pp. 47-57.

[8] Cassidy, F.G. Jamaica talk: three hundred years of the English language in Jamaica. London; 1961, pp.21-23,161-162.

[9] Selvon, Samuel. The Lonely Londoners. London: Penguin, 2006.

[10] Rhys, Jean. Wide Sargasso Sea, 1969.

[11] Hancock, Ian F. A List of Place Names in the Pacific North-West derived from the Chinook Jargon with a Word-list of the Language, Vancouver, Vancouver Public Library, 1972.

[12] Leland, C.G. Pidgin English Sing-Song, London, Trubner; 
1876.

[13] Camp, De David. "The Field of Creole Language Studies.” in Latin American Research Review Vol. 3 No. 3 (summer); 1968, pp. 25-46.

[14] Whinnon, K. "The origin of the European-based Creoles and pidgins". Orbis $14 ; 1965$, pp. 509-527.

[15] Ibid.

[16] Hall, Robert A. Pidgin and Creole Languages. Ithaca, N.Y.: Cornell University Press, 1966.

[17] Mc Whrother, J. H. Identifying the Creole prototype vindicating a typological class. Language; 1998. pp. 790-816.

[18] Op. cit.

[19] Camp, De David. "The Field of Creole Language Studies." in Latin American Research Review Vol. 3 No. 3 (summer); 1968. pp. 25-46.

[20] Aceto, M. "Looking Beyond Decreolization as an Explanatory Model of Language Change in Creole-speaking communities." in Journal of Pidgin and Creole Languages 14(1); 1999. pp. 93-199.

[21] Op. cit.

[22] Bickerton, Derek. Dynamics of a Creole System. London: Cambridge University Press; 1975.

[23] Ibid.

[24] Carden, G. \& Stewart, W. Binding Theory, Bioprogram,and Creolization: evidence from Haitian Creole.Journal of Pidgin and Creole Languages; 1988, pp. 1-68.

[25] Berry, J. "English loan words and adaptations" in Sierra Leone Krio'in La Page, Proceedings; 1961, pp. 1-16.

[26] Op. cit.

[27] Porras, Jorge E. "The Spanish Language in the Americas 500 Years After: Unity Within Diversity." Diaspora: Journal of the Annual Afro-Hispanic Literature and Culture Conference 212 (Spring); 1993, pp. 181.

[28] Devonish, Hubert. "The Language Heritage of the Caribbean: Linguistic Genocide and Resistance". Glossa, Vol 5, No.1 (March 2010). Universidad del Turabo: School of Social Sciences and Humanities, Puerto Rico, pp. 2-3.

[29] Op. cit.

[30] Op. cit.

[31] Lawrence, C. D. The Status of Creole in the Caribbean. 1999. Caribbean Quarterly. 45(2-3); 1999, pp. 41-51.

[32] Sen, Amartya. Identity and Violence: The Illusion of Destiny.
New York: W.W. Norton \& Co; 2006, pp.2-3.

[33] Op.cit.

[34] Balutansky, K. M. and Sourieau, M. A. (eds.) Caribbean Creolization: Reflections On the Cultural Dynamics of Language, Literature, and Identity. University Press of Florida, Florida; 1988, pp. 3.

[35] Glissant, Edouard. Caribbean Discourse: Selected Essays, translated and with an introduction by J. Michael Dash, Charlottesville, University Press of Virginia; 1989.

[36] Safa, H. (1987). "Popular Culture, National Identity, and Race in the Caribbean" in New West Indian Guide, Vol. 61, No. 3 \& 4; 1987, pp. 115-126.

[37] Lewis, Gordon, K. Main currents in Caribbean thought. Baltimore: The Johns Hopkins University Press; 1983.

[38] Harris, Wilson. (1998). "Creoleness: The Crossroads of a Civilization?", in: Balutansky, K. M. and Sourieau, M. A. (eds.), Caribbean Creolization: Reflections On the Cultural Dynamics of Language, Literature, and Identity. University Press of Florida, Florida; 1998, pp. 23-35.

[39] D'Aguiar, Fred. The Longest Memory: A Novel. New York: Pantheon Books, 1994.

[40] Op.cit.

[41] Op. cit.

[42] Op. cit.

[43] Op. cit.

[44] Op. cit.

[45] Op.cit.

[46] Vicioso, (Chiqui) Sherezada. "Dominicanyorkness: A Metropolitan Discovery of the Triangle", in: Balutansky, K. M. and Sourieau, M. A. (eds.), Caribbean Creolization: Reflections On the Cultural Dynamics of Language, Literature, and Identity. University Press of Florida, Florida; 1998, pp. 62-67.

[47] Freyre, Gilberto. The Masters and the Slaves: (Casa-Grande \& Senzala) A Study in the Development of Brazilian Civilization. New York: Knopf; 1956.

[48] Op.cit.

[49] Roemer, H. Astrid. "Who's Afraid of the Winti Spirit?", in: Balutansky, K. M. and Sourieau, M. A. (eds.), Caribbean Creolization: Reflections On the Cultural Dynamics of Language, Literature, and Identity. University Press of Florida, Florida; 1998, 44-52.

[50] Op. cit. 